\title{
IL-17A potentiates TNF $\alpha$-induced secretion from human endothelial cells and alters barrier functions controlling neutrophils rights of passage
}

\author{
Markus H. Bosteen • Katerina Tritsaris • \\ Anker J. Hansen • Steen Dissing
}

Received: 7 February 2013 /Revised: 1 September 2013 / Accepted: 9 September 2013 /Published online: 27 September 2013

(C) The Author(s) 2013. This article is published with open access at Springerlink.com

\begin{abstract}
Interleukin-17A (IL-17A) is an important proinflammatory cytokine that regulates leukocyte mobilization and recruitment. To better understand how IL-17A controls leukocyte trafficking across capillaries in the peripheral blood circulation, we used primary human dermal microvascular endothelial cells (HDMEC) to investigate their secretory potential and barrier function when activated with IL-17A and $\mathrm{TNF} \alpha$. Activation by TNF $\alpha$ and IL-17A causes phosphorylation of $\mathrm{p} 38$ as well as $\mathrm{I} \kappa \mathrm{B} \alpha$ whereby NFKB subsequently becomes phosphorylated, a mechanism that initiates transcription of adhesion molecules such as E-selectin. Members of the neutrophil-specific GRO-family chemokines were significantly up-regulated upon IL-17A stimulation on the mRNA and protein level, whereas all tested non-neutrophil-specific chemokines remained unchanged in comparison. Moreover, a striking synergistic effect in the induction of granulocyte colony-stimulating factors (G-CSF) was elicited when IL-17A was used in combination with TNF $\alpha$, and IL-17A was able to significantly augment the levels of TNF $\alpha$-induced E-selectin and ICAM-1. In accordance with this observation, IL-17A was able to markedly increase TNF $\alpha$-induced neutrophil adherence to HDMEC monolayers in an in vitro adhesion assay.
\end{abstract}

\author{
M. H. Bosteen $\cdot$ K. Tritsaris $\cdot$ S. Dissing $(\varangle)$ \\ Department of Cellular and Molecular Medicine (ICMM), Center for \\ Healthy Aging, Faculty of Health Sciences, University of \\ Copenhagen, Panum Institute, Building 12.6, Blegdamsvej 3B, \\ 2200 Copenhagen N, Denmark \\ e-mail: sdissing@sund.ku.dk \\ M. H. Bosteen \\ e-mail: bosteen@sund.ku.dk \\ K. Tritsaris \\ e-mail: ktrit@sund.ku.dk
}

\section{A. J. Hansen}

Department of Immunobiology, Novo Nordisk A/S,

Novo Nordisk Park, DK-2760 Måløv, Denmark

e-mail: ajh@novonordisk.com
Using a trans-well migration assay with an HDMEC monolayer as a barrier, we here show that pre-stimulating the endothelial cells with TNF $\alpha$ and IL-17A together enhances the rate of neutrophil transmigration compared to TNF $\alpha$ or IL$17 \mathrm{~A}$ alone. These results show that IL-17A and TNF $\alpha$ act in cooperation to facilitate neutrophil migration across the endothelial cell barrier. In addition, the synergistic actions of IL17A with TNF $\alpha$ to secrete G-CSF appear to be important for mobilizing neutrophils from the bone marrow to the blood stream.

Keywords Neutrophils · Endothelial cells · IL-17A - TNF $\alpha$. E-selectin

\section{Introduction}

The interleukin-17 (IL-17) family comprises six members, IL17A through IL-17F [33]. Of these, IL-17A is best described and is believed to play an important role in regulating monocyte and neutrophil recruitment during inflammatory conditions [25]. IL-17A is produced primarily by Th17 cells [56] which have been implicated in the pathogenesis of autoimmune and inflammatory diseases in humans [24]. By binding to its trans-membrane receptor complex, consisting of the IL-17RA and IL-17RC subunits, IL-17A affects the expression of many genes involved in inflammatory processes, but the exact expressional pattern varies considerably depending on cell type [35]. The IL-17 receptor is ubiquitously expressed, and IL-17A target genes have been reported to include a multitude of cytokines such as IL- $1 \beta$, TNF $\alpha$, IL-6 and granulocyte colony-stimulating factor (G-CSF) as well as chemokines including CXCL1, CXCL8 and CXCL10. Other regulated genes include several members of the $\mathrm{C}-\mathrm{C}$ motif family of chemokines and various anti-microbial peptides. The expression of many non-secreted molecules such as 
ICAM-1, iNOS and COX-2 is also affected by IL-17A, further supporting its role as a pro-inflammatory cytokine [23, 35]. Furthermore, IL-17 receptor knock-out mice have accelerated disease progression and suffer early deaths, as a result of impaired neutrophil recruitment, when challenged with Klebsiella pneumonia [55]. In patients with inflammatory bowel disease, the numbers of IL-17A-producing T-cells and serum levels of IL-17A correlate with disease severity [15]. Moreover, patients suffering from psoriasis have increased serum levels of IL-17A, strongly indicating an involvement of this molecule in auto-immunity [46]. It has also been shown that the number of IL-17A-producing T-cells is significantly increased in aged individuals compared to young healthy ones, implicating a role for IL-17A in ageing processes [36].

The ability of IL-17A to stimulate the maturation/ mobilization as well as the recruitment of neutrophils to sites of inflammation is heavily supported in the literature. Initially, Fossiez et al. [13] found that IL-17A-stimulated fibroblasts produced G-CSF and IL-8. Subsequently, Witowski et al. [50, 51] demonstrated that G-CSF and GRO $\alpha$ derived from mesothelial cells caused massive peritoneal neutrophil infiltration when IL-17A was administered as an i.p. bolus. Moreover, Schwarzenberger et al. [42] showed that adenovirus-mediated IL-17A over-expression caused increased levels of G-CSF which correlated with a marked neutrophilia in mice. IL-17A also promotes the expression of the neutrophil-specific chemokine IL-8 in different cell types such as intestinal epithelial cells, keratinocytes and airway endothelial cells [2, 10, 32, 39]. IL$17 \mathrm{~A}$ has likewise been reported to augment the production of several non-neutrophil-specific cytokines, including GM-CSF, MCP-1 and CCL20, in various cell types such as vascular smooth muscle cells, rheumatoid synoviocytes, endothelial cells and endometriotic stromal cells $[8,9,13,22,37]$. The fact that so many cell types express the IL-17 receptor makes it difficult to evaluate the relative contribution of each to the inflammatory milieu. Moreover, IL-17A has been reported to interact with other pro-inflammatory cytokines such as TNF $\alpha$ and IL-1 $\beta$, making it even more difficult to decipher its specific actions $[8,9]$. Thus, the exact role of IL-17A during inflammation is still unclear. We hypothesized that the effect of IL-17A is highly dependent on the cell and/or tissue context and therefore set out to investigate the role of this cytokine in an isolated system of human dermal microvascular endothelial cells. Our goal was to characterize the specific effects of IL-17A, focusing on the interaction between IL-17A and TNF $\alpha$ and their role in regulating neutrophil biology via the microvascular endothelium. We also hypothesized that the effects of IL-17 alone are small compared to those of TNF $\alpha$ and that the true importance of IL-17A can only be seen in combination with TNF $\alpha$. Here, we show that in the human microvascular endothelium, IL-17 and TNF $\alpha$ interact in the endothelial cells by causing granulocyte mobilization via adhesion molecule expression and cytokine secretion.

\section{Materials and methods}

\section{Reagents}

Recombinant human (rh)IL-17A and recombinant human $(\mathrm{rh}) \mathrm{TNF} \alpha$ were obtained from R\&D systems (Abingdon, UK). Bovine fibrinogen and bovine ferricytochrome $\mathrm{C}$ as well as phorbol 12-myristate 13-acetate (PMA) and $N$-formyl-Lmethionyl-L-leucyl-L-phenylalanine (fMLP) was from Sigma (St. Louis, MO, USA). Calcein-AM, SYBR ${ }^{\circledR}$ Safe DNA stain and rabbit anti-p38 $\left(\mathrm{pT}^{180} / \mathrm{pY}^{182}\right)$ were from Invitrogen (Carlsbad, CA, USA). Rabbit anti-IkB $\alpha$ binding [pSpS32/ 36] and rabbit anti-NFkB binding [pS529] antibodies were from Biosource International Inc., USA. Mouse anti-GAPDH was from Millipore (Billerica, MA, USA). Human P-selectin/ CD62P blocking antibody, human E-selectin/CD62E blocking antibody and isotype control antibody were from R\&D systems (Abingdon, UK). Collagen I (rat tail) was from Becton Dickinson (Franklin Lakes, NJ, USA).

\section{Cell lines and cell culture}

Human dermal microvascular endothelial cells (HDMEC) and human umbilical vein endothelial cells (HUVEC) were purchased from Promocell (Heidelberg, Germany). The cells were cultured in tissue-culture-treated collagen-I-coated $(50 \mu \mathrm{g} / \mathrm{ml})$ flasks using basal MCDB-131 medium supplemented with $5 \%$ FCS, $0.4 \%$ endothelial cell growth supplement (ECGS), $10 \mathrm{ng} / \mathrm{ml}$ epidermal growth factor (EGF), $1 \mu \mathrm{g} / \mathrm{ml}$ hydrocortisone, $200 \mathrm{U} / \mathrm{ml}$ penicillin and $50 \mu \mathrm{g} / \mathrm{ml}$ streptomycin. Medium and all supplements except antibiotics were purchased from Promocell. The cells were used until the ninth passage. For all experiments, HDMEC and HUVEC were cultured on collagen-I-coated $(50 \mu \mathrm{g} / \mathrm{ml})$ materials.

Human neutrophils were isolated from whole venous blood obtained from a healthy donor by centrifugation on a discontinuous density gradient of Ficoll-Hypaque with subsequent hypotonic lysis of red blood cells. Neutrophil viability was evaluated by trypan blue exclusion and was found to be $>$ $95 \%$ routinely. The percentage of isolated cells displaying a non-neutrophil morphology was found to be less than $5 \%$.

\section{RNA purification}

Cells were grown until (newly) confluent in 24-well or 6-well plates. Subsequently, their growth medium was exchanged with fresh medium, and the cells were stimulated with cytokines. Total RNA was extracted using the RNeasy ${ }^{\circledR}$ mini kit from Qiagen (Hilden, Germany) according to the manufacturer's instructions. 
Quantitative real-time PCR

RNA was extracted and reverse-transcribed using the Omniscript ${ }^{\circledR}$ mini kit from Qiagen according to the manufacturer's instructions. Quantitative real-time PCR (qRT-PCR) was performed in 96-well plate format using SYBR greenbased detection on an $\mathrm{Mx} 3000 \mathrm{P}^{\mathrm{TM}}$ thermal cycler from Agilent Technologies (Santa Clara, CA, USA). Each reaction contained $1 \times$ Brilliant $^{\circledR}$ SYBR ${ }^{\circledR}$ green QPCR master mix from Agilent Technologies. The plate was sealed and cycled under the following conditions: $95^{\circ} \mathrm{C}$ for $10 \mathrm{~min}, 40$ cycles of $95{ }^{\circ} \mathrm{C}$ for $30 \mathrm{~s}$ (melting), 40 cycles of $55-62{ }^{\circ} \mathrm{C}$ for $60 \mathrm{~s}$ (annealing) and 40 cycles of $72{ }^{\circ} \mathrm{C}$ for $60 \mathrm{~s}$ (elongation) (Table 1). Each reaction was performed in triplicate. Triplicate reactions for detection of GAPDH mRNA levels were used for normalization between samples. Fold changes were determined from cycle threshold values using the $\Delta \Delta \mathrm{C}_{\mathrm{T}}$ method. Sequences of primers used were as shown in Table 1.

\section{FACS method}

The surface expression of IL-17R on HDMECs was assessed using flow cytometry. Cultures of HDMEC were harvested using a VERSENE chelating medium (containing EDTA, DOW, USA) and washed in PBS with $5 \%$ FCS and stained with Alexa Fluor ${ }^{\circledR} 647$ (Red A) anti-human CD217 (IL17RA) antibody (\# 340903 Biolegend, San Diego, CA, USA) and as a control mouse IgG1 K Isotype (Yellow A) (\# 12-4714 eBioscience, San Diego, CA, USA) for $30 \mathrm{~min}$ in the dark at $4{ }^{\circ} \mathrm{C}$. Data acquisition and analysis were done using a FACSArray $^{\mathrm{TM}}$ (BD Biosciences).

\section{Western blotting}

Cells were grown to $90 \%$ confluence in tissue-culture-treated polystyrene petri-dishes and serum-starved in serum-free basal medium containing $2 \%$ FCS for 90 min before stimulation. After stimulation, the medium was aspirated, and all reactions were stopped by the addition of lysis buffer. The lysates were analysed by western blotting as described previously [12].

\section{ELISA}

Cells were grown until (newly) confluent in 24-well or 12well plates. Subsequently, their growth medium was exchanged with fresh medium, and the cells were stimulated with cytokines.

Human IL-8, CXCL10, GRO $\alpha$, G-CSF, E-selectin, VCAM-1 and ICAM-1 DuoSet ELISA kits were purchased from R\&D Systems. Cell supernatant or whole cell lysate was collected after cell stimulation and stored at $-20{ }^{\circ} \mathrm{C}$ until used for quantification. The total amount of target proteins in the lysate from each well was normalized to the total amount of cells by labelling with SYBR $^{\circledR}$ Safe DNA stain $(10.000 \times$ concentrate diluted to $5 \times$ concentrate) added directly to the lysis buffer. The amount of fluorescence (proportional to the number of cells) was determined using a Synergy HT microplate reader from BioTek $^{\circledR}$ (Winooski, VT, USA).

Neutrophil adhesion assay

\section{Neutrophil adhesion to fibrinogen}

Freshly isolated human neutrophils, which had been loaded in advance with calcein $(1 \mu \mathrm{M})$ for $45 \mathrm{~min}$ at room temperature, were added to each well $\left(1.5 \times 10^{5}\right.$ cells/well $)$ of a 96 -well plate which had been pre-coated for $3 \mathrm{~h}$ at room temperature using a solution of $1 \mathrm{mg} / \mathrm{ml}$ bovine fibrinogen in PBS without $\mathrm{Ca}^{2+} / \mathrm{Mg}^{2+}$. Cells were allowed to adhere for $30 \mathrm{~min}$ in the presence of either IL-17A or fMLF as a positive control. Fluorescence was measured (485 nm excitation, $520 \mathrm{~nm}$ emission) immediately hereafter using a Synergy $H T$ microplate reader from BioTek $^{\circledR}$ and then measured again after the wells had been washed twice with PBS. Neutrophil adherence was calculated according to the equation below.

\section{Neutrophil adhesion to HDMEC}

HDMEC were grown until (newly) confluent in 24-well plates. Subsequently, their growth medium was exchanged with fresh, and the cells were stimulated with cytokines. Afterwards, the cell monolayers were washed twice in adhesion buffer (MCDB-131 medium containing antibiotics and 10\% FCS). Then, freshly isolated human neutrophils, which had been loaded in advance with calcein $(1 \mu \mathrm{M})$ for $45 \mathrm{~min}$ at room temperature, were added to each well $\left(2-4 \times 10^{5}\right.$ cells/well $)$ and allowed to adhere for $20 \mathrm{~min}$. Fluorescence was measured (485 nm exCitation, $520 \mathrm{~nm}$ emission) immediately hereafter using a Synergy HT microplate reader from BioTek ${ }^{\circledR}$ and then measured again after the wells had been washed twice with PBS. Neutrophil adherence was calculated according to the equation below. In some experiments, anti-human P-selectin, anti-human E-selectin or isotype control antibodies were added to the endothelial cells $1 \mathrm{~h}$ before the addition of neutrophils. Immediately before adding neutrophils, unbound antibodies were washed away by three washes in adhesion buffer.

$\%$ Neutrophil adherence $=((R F U$ after wash-background $R F U) /$ $($ RFU before wash-background $R F U)) * 100$.

Transmigration assay

HDMEC were seeded (60,000/well) in the insert wells of 96-well Falcon $^{\mathrm{TM}}$ FluoroBlok ${ }^{\mathrm{TM}}$ plates $(8 \mu \mathrm{m})$ and allowed to reach confluence for $48 \mathrm{~h}$ before they were washed twice in growth 
Table 1 Primer sequences, annealing temperature and product sizes for the mRNA targets

\begin{tabular}{|c|c|c|c|c|}
\hline Target & Accession no. & Sequence $\left(5^{\prime}-3^{\prime}\right)$ & Annealing temperature $\left({ }^{\circ} \mathrm{C}\right)$ & Product size (bp) \\
\hline GAPDH & NM_002046.3 & $\begin{array}{l}\text { F: GGAAGGTGAAGGTCGGAGTCAA } \\
\text { R: GATCTCGCTCCTGGAAGATGGT }\end{array}$ & 60 & 240 \\
\hline E-selectin & NM_000450.2 & $\begin{array}{l}\text { F: CAGCCCAGGTTGAATGCACCA } \\
\text { R: AGGAAGACAATTCATGTAGCCTCGCTC }\end{array}$ & 62 & 116 \\
\hline IL17 RA & NM_014339.5 & $\begin{array}{l}\text { F: ACTTTGCCCACACCCAACAAG } \\
\text { R: TCGCTGGTGGAACTCTTCTGG }\end{array}$ & 60 & 548 \\
\hline IL17 RC & $\begin{array}{l}\text { NM_153460.3 } \\
\text { NM_153461.3 } \\
\text { NM_001203263.1 } \\
\text { NM_001203264.1 } \\
\text { NM_001203265.1 } \\
\text { NM_032732.5 }\end{array}$ & $\begin{array}{l}\text { F: AAGGAGACCGACTGTGACCTC } \\
\text { R: TCAGAGACATTCAGAACCAGATGC }\end{array}$ & 60 & $416 / 461$ \\
\hline VCAM-1 & NM_001078.2 & $\begin{array}{l}\text { F: ACCATGACCTGTTCCAGCGAGG } \\
\text { R: GGTCCAGGGGAGATCTCAACAGT }\end{array}$ & 62 & 236 \\
\hline GRO- $\gamma$ & NM_002090.2 & $\begin{array}{l}\text { F: AGCTTGTCTCAACCCCGCATC } \\
\text { R: ATTTTCAGCTCTGGTAAGGGCAGGG }\end{array}$ & 60 & 156 \\
\hline G-CSF & NM_000759.3 & $\begin{array}{l}\text { F: CACCCAGAGCCCCATGAAGCT } \\
\text { R: GCACAGCTTGTAGGTGGCACACTC }\end{array}$ & 60 & 211 \\
\hline MCP-1 & NM_002982.3 & $\begin{array}{l}\text { F: CTCAGTGCAGAGGCTCGCGAG } \\
\text { R: ACAGGGTGTCTGGGGAAAGCT }\end{array}$ & 60 & 240 \\
\hline M-CSF & NM_000757.4 & $\begin{array}{l}\text { F: GGAGACCTCGTGCCAAATTA } \\
\text { R: TATCTCTGAAGCGCATGGTG }\end{array}$ & 55 & 128 \\
\hline CXCL11 & NM_005409.4 & $\begin{array}{l}\text { F: CATGAGTGTGAAGGGCATGGCT } \\
\text { R: CCAGGGCCTATGCAAAGACAGCG }\end{array}$ & 61 & 108 \\
\hline CXCL10 & NM_001565.2 & $\begin{array}{l}\text { F: CCTGCAAGCCAATTTTGTCCACGT } \\
\text { R: GCAGCCTCTGTGTGGTCCATCC }\end{array}$ & 61 & 202 \\
\hline
\end{tabular}

medium and subsequently stimulated with cytokines. After stimulation, the cell monolayers were washed twice in transmigration buffer (MCDB-131 medium containing antibiotics and $10 \%$ FCS). Then, freshly isolated human neutrophils, which had been loaded in advance with calcein $(1 \mu \mathrm{M})$ for $45 \mathrm{~min}$ at room temperature, were added to each insert well $\left(1 \times 10^{5}\right.$ cells/well $)$ and allowed to transmigrate for $90 \mathrm{~min}$. Fluorescence was measured (485 nm excitation, $520 \mathrm{~nm}$ emission) immediately hereafter using a Synergy HT microplate reader from BioTek ${ }^{\circledR}$. Neutrophils appearing on the endothelial cell layer after transmigration were visualized using a fluorescence microscope with a $20 \times 0.75$ numeric aperture objective from Olympus (Japan) and a MetaMorph Imaging system as previously described [21].

Measurements of superoxide radical generation

The ability of human neutrophils to generate superoxide anion was assayed by the reduction of bovine ferricytochrome $\mathrm{C}$. Freshly isolated human neutrophils were re-suspended in a modified phosphate-buffered Krebs-Ringer solution containing $1 \mathrm{mM}$ glucose. The cell suspension $\left(7.5 \times 10^{5}\right.$ cells $\left./ \mathrm{ml}\right)$ was distributed in the wells of a polystyrene tissue-culture-treated 96-well plate $(200 \mu \mathrm{l} /$ well $)$ which had been pre-coated for $3 \mathrm{~h}$ at room temperature using a solution of $1 \mathrm{mg} / \mathrm{ml}$ bovine fibrinogen in PBS without $\mathrm{Ca}^{2+} / \mathrm{Mg}^{2+}$. Then, $20 \mu \mathrm{l}$ of ferricytochrome C $\left(10 \mathrm{mg} / \mathrm{ml}\right.$ in PBS without $\left.\mathrm{Ca}^{2+} / \mathrm{Mg}^{2+}\right)$ was added to a final concentration of $75 \mu \mathrm{M}$. The cells were allowed to adhere for $1 \mathrm{~h}$ prior to the addition of stimulators. The relative amount of superoxide anion formation was measured by reading the absorbance of reduced cytochrome $\mathrm{C}$ at $550 \mathrm{~nm}$ in a Synergy HT microplate reader from BioTek ${ }^{\circledR}$ with $630 \mathrm{~nm}$ as reference.

Statistical evaluations

Data are presented as means \pm standard deviation (SD). Statistical evaluation of the results was made by a two-tailed Student's $t$-test not assuming equal variance between groups. $P$ values are indicated with $* \leq 0.05, * * \leq 0.01$ and $* * * \leq 0.001$.

\section{Results}

Human microvascular endothelial cells express the IL-17A receptor

Our first objective was to verify the ability of HDMEC to signal through the IL-17A receptor. The precise molecular 
composition with regards to stoichiometry and structure of the IL-17 receptor is still unclear, but it is believed that at least two subunits, IL-17RA and IL-17RC are necessary to make up a functional receptor complex for signalling upon IL-17A binding [16]. By reverse transcription of total cellular RNA followed by PCR amplification using IL-17RA and IL17RC transcript selective primers (intron spanning), we identified the presence of these transcripts in HDMEC (Fig. 1a). In addition, FACS analysis revealed a low expression of IL17RA in unstimulated HDMEC comprising $25 \%$ of the cell population (Fig. 1b).

When HDMEC were stimulated with IL-17A phosphorylation of the MAP kinase, p38 was significantly increased after $20 \mathrm{~min}$ (Fig. 1c, d). p38 phosphorylation by IL-17A was reported previously in other cell types [3, 38, 44].
Figure 1c, $d$ also shows the powerful effect of TNF $\alpha$ on $\mathrm{p} 38$ phosphorylation both in the presence and absence of IL-17A. The effect is sustained over $30 \mathrm{~min}$ and several fold larger than the effect of IL-17A alone. TNF $\alpha$ is known to be a powerful activator of $\mathrm{NF} \kappa \mathrm{B}$, and we therefore investigated the role of both IL-17A and TNF $\alpha$ in the activation process. We, at first, determined the phosphorylation of $\mathrm{I} \kappa \mathrm{B} \alpha$ that releases the NFkB complex for influx into the nucleus. We found that $\mathrm{I} \kappa \mathrm{B} \alpha$ is phosphorylated following $\mathrm{TNF} \alpha$ stimulation with and without IL-17A after $10 \mathrm{~min}$, but phosphorylation was undetectable after $20 \mathrm{~min}$. The consequence of this phosphorylation is the subsequent phosphorylation of NFKB. Stimulation with TNF $\alpha$ and TNF $\alpha+$ IL-17A results in a powerful phosphorylation of $\mathrm{NF} \kappa \mathrm{B}$ after $10 \mathrm{~min}$, and the effect is detectable up to $30 \mathrm{~min}$ (Fig. 1c, d).
Fig. 1 Human microvascular endothelial cells express and signal through the IL-17A receptor. a Agarose-gel photos showing PCR products for IL17RA (548 bp) and IL-17RC (416 bp) at the predicted band sizes loaded next to a DNA ladder for band size determination. $\mathbf{b}$ Expression of IL-17 receptor A (IL-17RA) on human dermal microvascular endothelial cells (HDMECs) as shown by surface binding of IL-17RA antibody (black curve) compared to control IgG1 antibody (grey curve) using a BD FACSArray. The mean fluorescent intensity (MFI) is 99 for control and 689 for IL-17RA antibody. One representative experiment out of three. $\mathbf{c}$ Western blotting showing phosphorylation of p38 (P-p38), $\mathrm{I} \kappa \mathrm{B} \alpha(\mathrm{P}-\mathrm{I} \kappa \mathrm{B} \alpha)$ and NFkB (P$\mathrm{NF} \kappa \mathrm{B}$ ) after stimulation with IL17A $(50 \mathrm{ng} / \mathrm{ml})$ and $\mathrm{TNF} \alpha$ $(10 \mathrm{ng} / \mathrm{ml})$ alone or together. $\mathbf{d}$ Measurements of grey values from the Western blotting of $\mathrm{P}$ p38 and P-NFKB

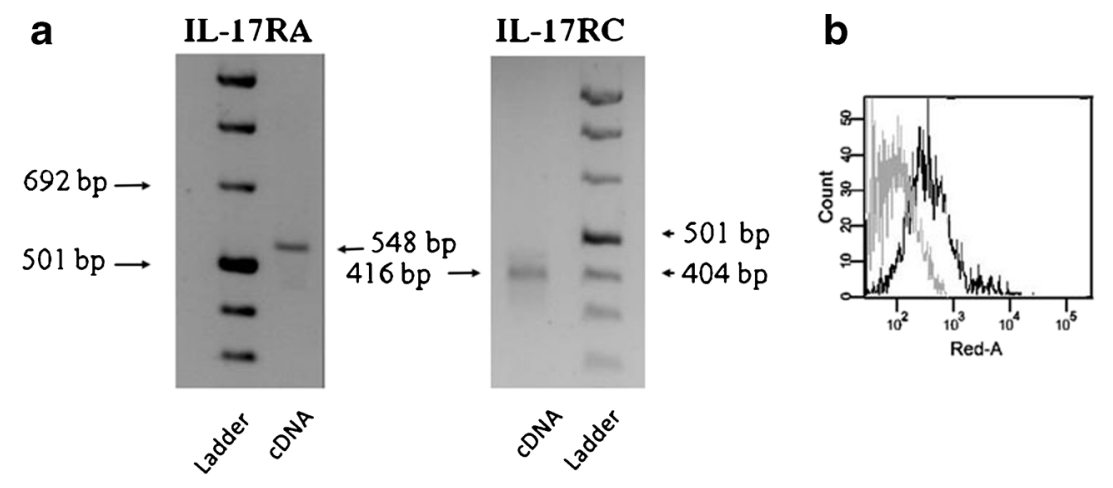

C
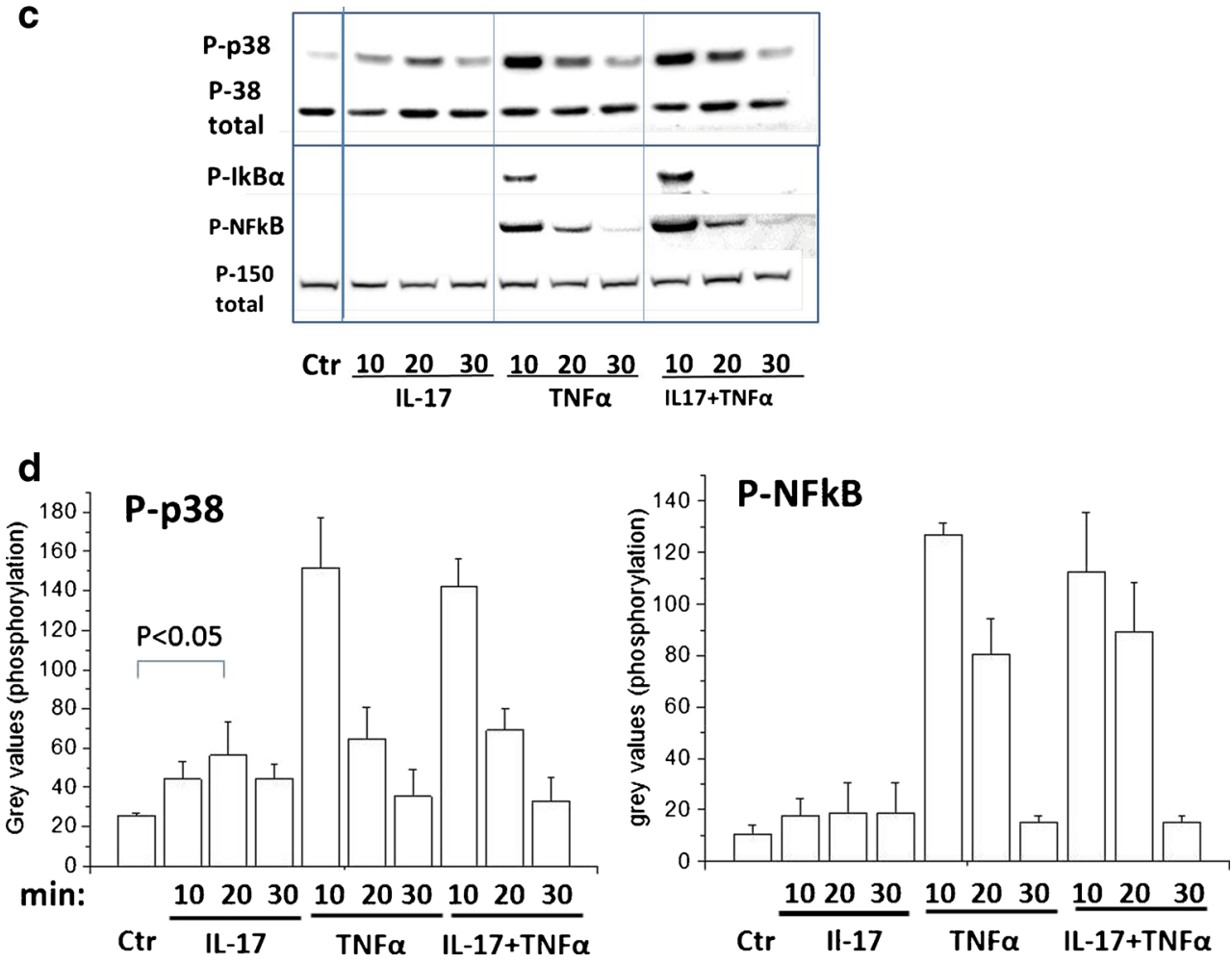
IL-17A cooperates with TNF $\alpha$ in the induction of G-CSF and GRO-family chemokines

IL-17A plays an important role in recruiting monocytes and neutrophils to sites of inflammation [45]. We therefore investigated whether IL-17A regulated the expression of CSFs which are known to affect leukocyte mobilization and recruitment by mediating their maturation and release from the bone marrow [7].

Using qRT-PCR and ELISA, we found that IL-17A specifically enhanced HDMEC expression of G-CSF on both mRNA and protein level and that IL-17A could function in synergy with TNF $\alpha$ in this effect (Fig. 2a, b). Similar results were obtained using HUVEC as analysed by qRT-PCR (data not shown). In marked contrast, there was no interaction between IL-17A and TNF $\alpha$ on HDMEC expression of macrophage-CSF (M-CSF) (Table 2) for which TNF $\alpha$ alone was a strong inducer (data not shown).

Chemokines are cytokines which act as chemoattractants facilitating leukocyte adhesion and migration across the endothelium [45]. We therefore investigated if some of the chemokines previously reported to be regulated by IL-17A would also be regulated in HDMEC. IL-17A caused an upregulation of $\mathrm{GRO} \alpha \mathrm{mRNA}$ expression and protein secretion albeit to a lesser extent than TNF $\alpha$ (Fig. 2c, d). However, when the cells were challenged with IL-17A together with $\mathrm{TNF} \alpha, \mathrm{GRO} \alpha$ production rose to levels higher than those seen when stimulating with either alone (Fig. 2c, d). Similar results were obtained using HUVEC as analysed by qRT-PCR (data not shown). TNF $\alpha$ was also a potent inducer of GRO- $\gamma$ (CXCL3) mRNA expression which, like GRO $\alpha$, could be further enhanced in combination with IL-17A (Table 2). Among the cytokines tested in this study, IL-17A seems specific for GRO-family chemokine secretion as levels of other chemokines such as CXCL10, CXCL11 and MCP-1 were not affected (Fig. 2f and Table 2) albeit potently induced by $\mathrm{TNF} \alpha$ (Fig. $2 \mathrm{f}$ and data not shown). Interestingly, the expression of IL-8, which has previously been reported to be regulated by IL-17A in endothelial cells [39] and which is similar to GRO-family chemokines in terms of structure and function, was not significantly affected by IL-17A in HDMEC (Fig. 2e).

\section{IL-17A potentiates TNF $\alpha$-induced E-selectin and ICAM-1 expression}

Adhesion molecules such as E-selectin, ICAM-1 and VCAM1 on the surface of the endothelium mediate attachment and transmigration of circulating leukocytes, facilitating their recruitment to extravascular tissues [45]. We therefore investigated if IL-17A could modulate the expression of these molecules. When HDMEC were challenged with TNF $\alpha$ in combination with IL-17A, E-selectin levels were significantly augmented between 8 and $32 \mathrm{~h}$ of stimulation as compared to treatment with TNF $\alpha$ alone (Fig. 3a). After 32 h, levels of E-selectin were still significantly elevated compared to
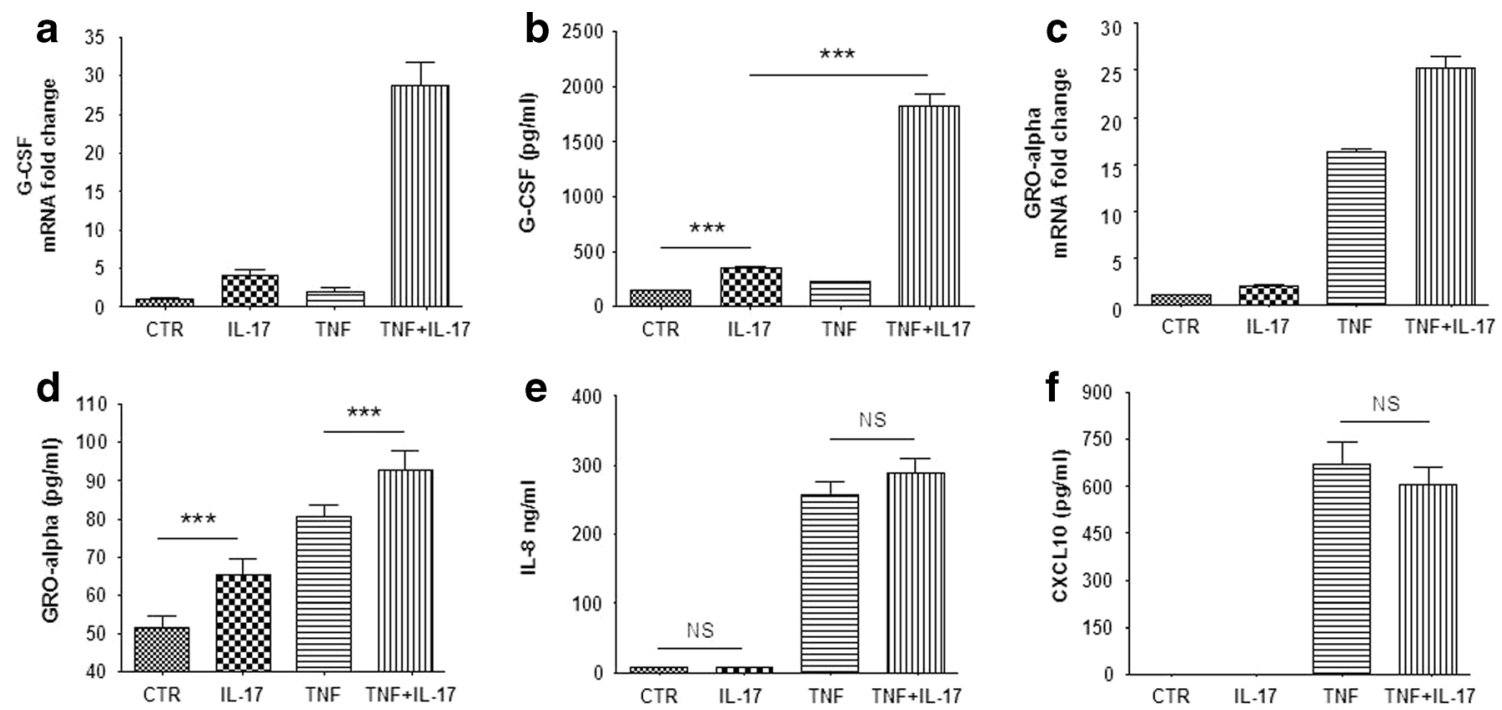

Fig. 2 IL-17A cooperates with TNF $\alpha$ in the induction of G-CSF and GRO-family chemokines. a Relative mRNA levels of G-CSF in HDMEC challenged with IL-17A $(50 \mathrm{ng} / \mathrm{ml}), \mathrm{TNF} \alpha(2 \mathrm{ng} / \mathrm{ml})$ or both for $4 \mathrm{~h}$ (means of technical triplicates). b Protein levels of secreted G-CSF from HDMEC challenged with IL-17A $(50 \mathrm{ng} / \mathrm{ml}), \mathrm{TNF} \alpha(2 \mathrm{ng} / \mathrm{ml})$ or both for $24 \mathrm{~h}$. $\mathbf{c}$ Relative mRNA levels of GRO $\alpha$ in HDMEC challenged with IL-17A $(50 \mathrm{ng} / \mathrm{ml}), \mathrm{TNF} \alpha(10 \mathrm{ng} / \mathrm{ml})$ or both for $4 \mathrm{~h}$ (means of technical triplicates). d Protein levels of secreted GRO $\alpha$ from HDMEC challenged with IL-17A (50 ng/ml), TNF $\alpha(10 \mathrm{ng} / \mathrm{ml})$ or both for $12 \mathrm{~h}$. e Protein levels of secreted IL-8 from HDMEC challenged with IL-17A $(50 \mathrm{ng} / \mathrm{ml}), \mathrm{TNF} \alpha(10 \mathrm{ng} / \mathrm{ml})$ or both for $24 \mathrm{~h}$. f Protein levels of secreted CXCL10 from HDMEC challenged with IL-17A (50 ng/ml), TNF $\alpha$ $(10 \mathrm{ng} / \mathrm{ml})$ or both for $24 \mathrm{~h}$. CXCL10 was undetectable in the CTRand IL-17A-treated samples. b, d, e and $\mathbf{f}$ are representative of two independent experiments 
Table 2 qRT-PCR data for HDMEC challenged with TNF $\alpha(2 \mathrm{ng} / \mathrm{ml})$ or a combination of TNF $\alpha$ and IL-17A $(100 \mathrm{ng} / \mathrm{ml})$ for $24 \mathrm{~h}$. The data represent mean values of triplicate samples. The results are representative of three independent experiments. Fold changes were calculated as (TNF + IL-17 / TNF) $=2^{\Delta \Delta C}$ T, representing the effect of IL-17A on TNF $\alpha$ challenged cells. NS means not significant $(p>0.05)$

\begin{tabular}{|c|c|c|c|c|c|c|}
\hline \multirow{2}{*}{$\frac{\text { Transcript }}{24 \mathrm{~h} \text { of stimulation }}$} & \multicolumn{2}{|c|}{ Average $\mathrm{C}_{\mathrm{T}}( \pm \mathrm{SD})$} & \multicolumn{2}{|c|}{$\Delta \mathrm{C}_{\mathrm{T}}$ normalized to $\mathrm{GAPDH}( \pm \mathrm{SD})$} & \multirow{2}{*}{$\frac{\Delta \Delta \mathrm{C}_{\mathrm{T}}}{\mathrm{TNF}-(\mathrm{TNF}+\mathrm{IL}-17)}$} & \multirow{2}{*}{$\begin{array}{l}\text { Fold change } \\
(\mathrm{TNF}+\mathrm{IL}-17) / \mathrm{TNF}\end{array}$} \\
\hline & $\mathrm{TNF}$ & $\mathrm{TNF}+\mathrm{IL}-17$ & $\mathrm{TNF}$ & $\mathrm{TNF}+\mathrm{IL}-17$ & & \\
\hline G-CSF & $34.17(0.07)$ & $26.88(0.23)$ & $15.36(0.16)$ & $7.99(0.17)$ & 7.37 & $166(P<0.001)$ \\
\hline M-CSF & $28.69(0.14)$ & $28.39(0.29)$ & $11.30(0.17)$ & $11.21(0.09)$ & -0.09 & $0.94(\mathrm{NS})$ \\
\hline GRO- $\gamma$ & $28.11(0.30)$ & $26.39(0.19)$ & $10.79(0.42)$ & $9.25(0.21)$ & 1.53 & $2.89(P=0.01)$ \\
\hline CXCL10 & $22.99(0.42)$ & $23.04(0.12)$ & $5.66(0.33)$ & $5.88(0.16)$ & -0.22 & $0.86(\mathrm{NS})$ \\
\hline CXCL11 & $24.24(0.35)$ & $24.16(0.08)$ & $6.92(0.23)$ & $7.02(0.20)$ & -0.11 & 0.93 (NS) \\
\hline MCP-1 & $17.32(0.35)$ & $16.86(0.10)$ & $0.08(0.22)$ & $0.31(0.19)$ & 0.23 & 1.18 (NS) \\
\hline E-selectin & $26.80(0.14)$ & $25.78(0.04)$ & $10.21(0.15)$ & $9.20(0.03)$ & 1.01 & $2.02(P<0.01)$ \\
\hline VCAM-1 & $25.86(0.04)$ & $26.21(0.11)$ & $9.32(0.08)$ & $9.63(0.13)$ & -0.31 & $0.80(P=0.05)$ \\
\hline
\end{tabular}

untreated cells (in which E-selectin was undetectable) and were approximately twofold higher in the presence of TNF $\alpha$ + IL-17A than in the presence of TNF $\alpha$ alone (Fig. 3a). We measured increased mRNA expressions for E-selectin between 4 and $24 \mathrm{~h}$ following TNF $\alpha$ stimulation that was further enhanced in the presence of IL-17 after 15-24 h (data not shown). The fold change of mRNA for a number of proteins as well as significance levels is shown in Table 2. These data are consistent with the finding that IL-17 enhances E-selectin expression in the presence of TNF $\alpha$ on the protein level as shown in Fig. 3a. mRNA for the other important cell adhesion protein $\mathrm{P}$-selectin did not show any up-regulated expression between 4 and $24 \mathrm{~h}$ when stimulated with TNF $\alpha$ with or without IL-17A (data not shown). Furthermore, Western blotting of P-selectin did not show any change in protein expression following IL-17A stimulation that is neither the fulllength nor the soluble P-selectin isoform (data not shown).

Levels of TNF $\alpha$-induced VCAM-1 were unaffected except for a slight decrease after $24 \mathrm{~h}$ (Fig. 3b). The results were confirmed at the mRNA level by qRT-PCR (Table 2). Furthermore, IL-17A also augmented TNF $\alpha$-induced ICAM-1 albeit to a modest extent (Fig. 3c). Untreated HDMEC expressed very low levels of adhesion molecules which could be modulated in the presence of IL-17A alone (data not shown). However, these effects were negligible in terms of potency compared to those of TNF $\alpha$ or TNF $\alpha+$ IL-17A.

It is not yet well documented how the synergistic effect between IL-17A and TNF $\alpha$ takes place, but it has been suggested that the mRNA stabilizing effects of Il-17A could play a role. In addition, the effect of activation of enhancer binding proteins $(\mathrm{C} / \mathrm{EBP})$ could be important as it has been shown in relation to IL-6 synthesis [40].

Elevated E-selectin levels by IL-17A correlate with increased leukocyte adhesion

E-selectin is crucial in the binding of leukocyte to the endothelium, and studies have shown that neutrophilic cells bind to
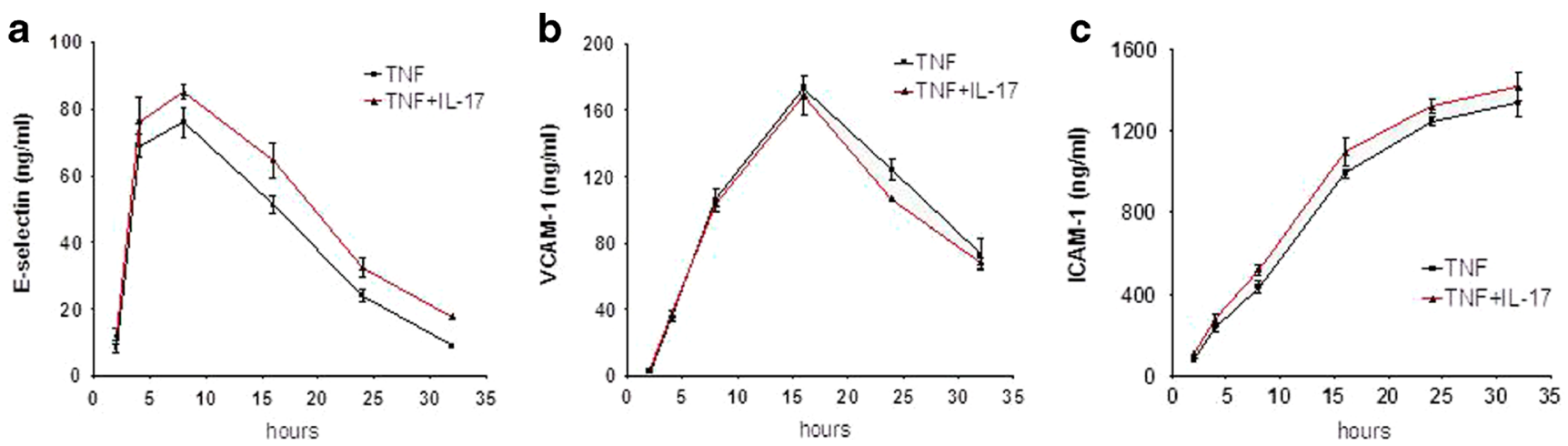

Fig. 3 IL-17A modulates TNF $\alpha$-induced E-selectin and ICAM-1 expression. a ELISA data showing cell-associated (lysate) protein levels of E-selectin in HDMEC when challenged with TNF $\alpha(2 \mathrm{ng} / \mathrm{ml})$ or TNF $\alpha$ in combination with IL-17A $(100 \mathrm{ng} / \mathrm{ml})$ for $2-32 \mathrm{~h}$. The effect of IL-17A was statistically significant at all time-points $(P<0.05)$ except at "4 h". b
Same as in a only for VCAM-1 protein. The effect of IL-17A was statistically significant at all time-points $(P<0.05)$ except at " 4 " and "32 h". c Same as in a only for ICAM-1 protein. The effect of IL-17A was only statistically significant at " $24 \mathrm{~h}$ " $(P<0.05)$. a, b and $\mathbf{c}$ are representative of two independent experiments 
endothelial cells in an E-selectin dependent manner [5, 30, 47]. We therefore investigated if the potentiating effect of IL$17 \mathrm{~A}$ on $\mathrm{TNF} \alpha$-induced E-selectin expression correlated with increased neutrophil adhesion. After $30 \mathrm{~h}$ of stimulation, the effect of TNF $\alpha+$ IL-17A was maximal relative to TNF $\alpha$ alone, and we therefore chose to investigate adhesion at this time-point. Figure $4 a$, b shows that IL-17A is able to significantly augment $\mathrm{TNF} \alpha$-stimulated adhesion of neutrophils to an HDMEC monolayer in a manner which mirrored the observed effect on E-selectin expression (Fig. 3a). The design of the experiments was such that neutrophils were at no point exposed to IL-17A or TNF $\alpha$ and the adhesion therefore solely reflects the change in expression pattern and behaviour of the endothelial cells. To investigate the specificity of the E-selectin effect on adhesion, we applied E-selectin and P-selectin blocking antibodies to HDMEC monolayers pretreated with either IL-17A, TNF $\alpha$ or both for $24 \mathrm{~h}$. E-selectin or P-selectin blocking antibodies were added $1 \mathrm{~h}$ before the addition of neutrophils. The data reveal that the E-selectin antibody significantly reduces the binding of neutrophils to the endothelial cells when pre-stimulated with $\mathrm{TNF} \alpha$ or $\mathrm{TNF} \alpha+$ IL-17A. P-selectin antibodies had no effects on adhesion. These data reveal that E-selectin expression plays a dominant role in the neutrophil adhesion and thus is one of the important factors for controlling the rate of passage across the endothelial cell layer as seen in Fig. 4c.

IL-17A causes increased neutrophil transmigration across an endothelial cell layer

Migration of neutrophils across the capillary wall is an important part of the inflammatory process that occurs after leukocytes have attached to the endothelium. E-selectin is essential in this context because it mediates the capturing of circulating leukocytes, causing them to roll along the endothelium. This, in turn, triggers integrins on their surface to interact with ICAM-1 and/or VCAM-1 resulting in a firm adherence [49]. We therefore hypothesized that IL-17A would be able to augment $\mathrm{TNF} \alpha$-stimulated transmigration of neutrophils. The passage of neutrophils across the endothelium was assayed using a trans-well migration-based experimental setup with confluent HDMEC layers as a barrier on both sides of the insert wells. The endothelial cells were pre-stimulated, and the stimulators were subsequently removed by washing prior to the addition of neutrophils to the insert wells. When HDMEC had been challenged with $\mathrm{TNF} \alpha$, the number of
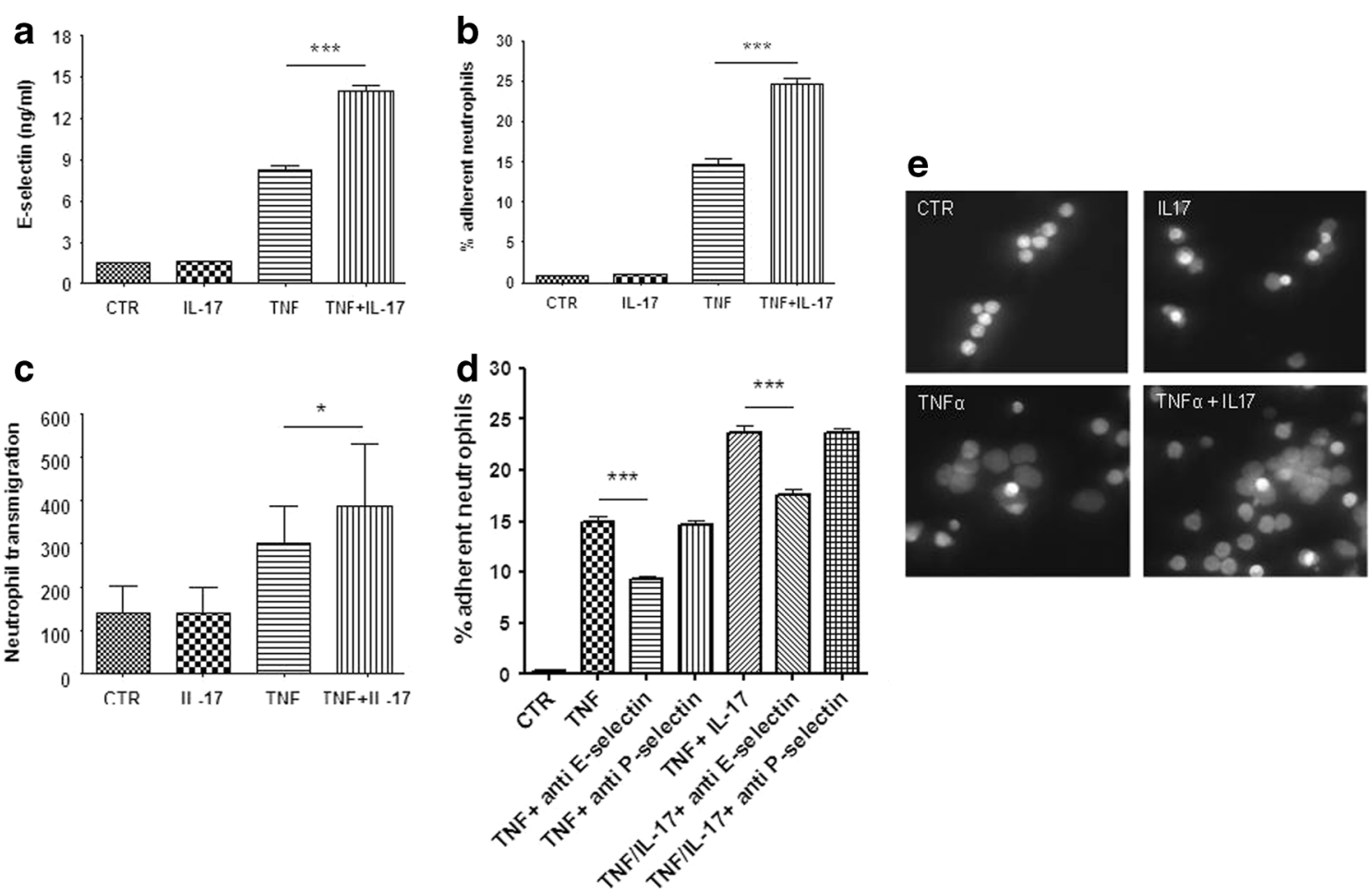

Fig. 4 IL-17A modulates TNF $\alpha$-induced neutrophil adhesion and transmigration. a ELISA data showing cell-associated (lysate) protein levels of E-selectin in HDMEC when challenged with IL-17A $(50 \mathrm{ng} / \mathrm{ml})$, $\mathrm{TNF} \alpha(1 \mathrm{ng} / \mathrm{ml})$ or both for $24 \mathrm{~h}$. b Relative number of neutrophils adhering to a confluent HDMEC monolayer pre-treated with either IL17A (100 ng/ml), TNF $\alpha(2 \mathrm{ng} / \mathrm{ml})$ or both for $30 \mathrm{~h}$. c Relative number of neutrophils that had transmigrated through a confluent HDMEC monolayer pre-treated with either IL-17A (100 ng/ml), TNF $\alpha(2 \mathrm{ng} / \mathrm{ml})$ or both for $30 \mathrm{~h} . \mathbf{a}, \mathbf{b}$ and $\mathbf{c}$ are representative of two independent experiments. $\mathbf{d}$ Relative number of neutrophils adhering to a confluent HDMEC monolayer pre-treated with either IL-17A $(100 \mathrm{ng} / \mathrm{ml}), \mathrm{TNF} \alpha(2 \mathrm{ng} / \mathrm{ml})$ or both for $24 \mathrm{~h}$. The cells were pre-treated with $25 \mu \mathrm{g} / \mathrm{ml}$ E-selectin or $1 \mu \mathrm{g} / \mathrm{ml}$ $\mathrm{P}$-selectin blocking antibodies for $1 \mathrm{~h}$ before the addition of neutrophils. $\mathrm{e}$ Photos of transmigrated neutrophils from $\mathbf{c}$ revealing the shape changes induced by TNF $\alpha$ with IL-17A 
transmigrating neutrophils rose significantly above control, and this effect could be further enhanced when TNF $\alpha$ had been present together with IL-17A (Fig. 4c). When neutrophils were visualized after passage, they appeared round and were loosely attached to the barrier in control and IL-17Astimulated conditions. When TNF $\alpha$ alone or in combination with IL-17A had been present, neutrophils (clearly) changed morphology after passage and adhered firmly to the endothelial surface with a large surface area (Fig. 4e). Thus, under conditions of potentiated E-selectin expression by IL-17A and $\mathrm{TNF} \alpha$ in combination, we observed an enhanced transmigration of neutrophils across a confluent HDMEC layer.

\section{IL-17A does not directly affect neutrophil activation}

In the adhesion and migration experiments, neutrophils were not exposed to TNF $\alpha$ or IL-17A. In this way, we could investigate the endothelial cell-mediated effect on neutrophil adhesion and migration without interference from potential activating effects of IL-17A directly on the neutrophils. To investigate if IL-17A had such a direct effect, we established a monoculture adhesion assay in which the neutrophils were allowed to adhere to a fibrinogen substratum in the presence of IL-17A. Several cytokines including IL-8 and TNF $\alpha$ have previously been reported to induce and/or potentiate/prime neutrophil activation as measured by their ability to adhere to matrix proteins and/or generate superoxide radicals $[11,20$, 53]. However, IL-17A was not able to induce adherence or generation of superoxide in neutrophils, nor was it able to prime/augment the effect of PMA and fMLP (Fig. 5a, b).

\section{Discussion}

In this study, we report that IL-17A in synchrony with TNF $\alpha$ potently induces endothelial cells to secrete chemokines important for mobilization and recruitment of neutrophils and

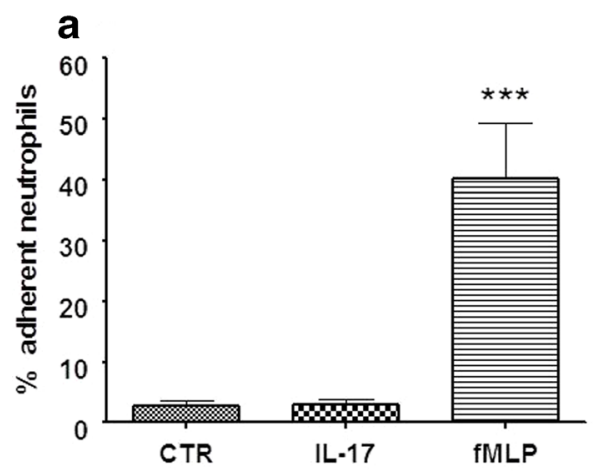

Fig. 5 IL-17A does not directly affect neutrophil adherence and function. a Data showing neutrophil adherence to a fibrinogen substratum when challenged with IL-17A $(50 \mathrm{ng} / \mathrm{ml})$ or fMLP $(1 \mu \mathrm{M})$ for $30 \mathrm{~min}$. b Data up-regulates proteins that serve as binding sites during their passage through the endothelial barrier.

Stimulation of HDMEC with IL-17A caused enhanced p38 phosphorylation, which, however, was much smaller than that observed in the presence of TNF $\alpha$ (Fig. 1c, d). TNF $\alpha$ with and without IL-17A caused phosphorylation of IKB $\alpha$ and subsequently phosphorylation of NFKB that has a binding site in the human E-selectin gene [41]. This is consistent with the augmented E-selectin synthesis observed on the protein level (Fig. 3a).

\section{Expression of E-selectin and P-selectin}

The inducible expression of P-selectin and E-selectin is regulating inflammation, but their expression is mediated through different pathways. In human endothelial cells, E-selectin is encoded by the SELE gene that requires binding of NFKB and the activating transcription factor -2 (ATF-2) [29]. Eselectin is not stored in vesicles in the cell, but mRNA is translated and protein is transported to the cell surface. In human endothelial cells, P-selectin is upon thrombin and histamine stimulation mobilized from storage granules to the plasma membrane. However, mRNA synthesis for P-selectin in human endothelial cells is encoded by the Selp gene that lacks binding sites for NFKB and ATF-2, and mRNA synthesis is not activated by TNF $\alpha$ but by IL-4 [54].We found that E-selectin mRNA is increased several fold between 4 and $16 \mathrm{~h}$ with TNF $\alpha+\mathrm{IL}-$ $17 \mathrm{~A}$ compared to unstimulated cells and that P-selectin mRNA is not increased, which are all consistent with the finding that different pathways are involved in their expressions. It is thus important to note that caution should be taken in comparing inflammatory mouse and human models due to the fact that Pselectin is expressed differently as pointed out by Liu et al. [29].

\section{Secretion of chemokines}

Endothelial stimulation with IL-17A caused a significant rise in the production of G-CSF and GRO $\alpha$ consistent with

\section{b}

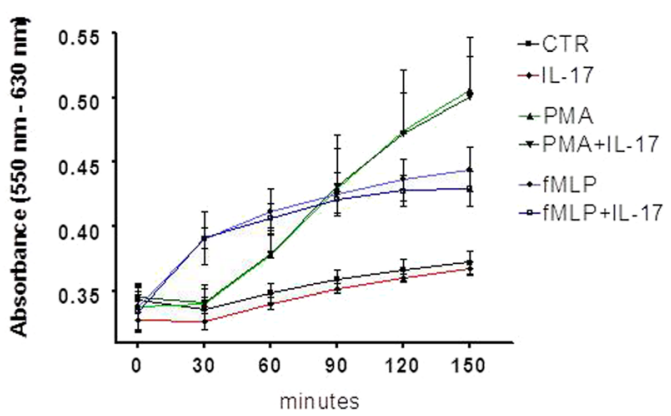

showing neutrophil superoxide radical generation, as measured by reduction of ferricytochrome C, when challenged with IL-17A $(50 \mathrm{ng} / \mathrm{ml})$, fMLP $(1 \mu \mathrm{M})$, PMA $(10 \mathrm{ng} / \mathrm{ml})$ or combinations of these 
previous observations in other cell types [13, 51]. IL-17A also caused an up-regulation of GRO- $\gamma$ as shown by qRT-PCR (Table 2), a chemokine which is believed to have effects similar to $\mathrm{GRO} \alpha$, i.e. function as a chemoattractant and a maturation factor specific for neutrophils $[1,14,48]$. Interestingly, we show that IL-8, another neutrophil-specific chemokine, is not significantly regulated by IL-17A in HDMEC, although this has been reported to be the case in human lung microvascular endothelial cells [39]. Neutrophils possess two receptors for IL-8 (CXCR1 and CXCR2), whereas GROfamily chemokines can only bind CXCR2 [1]. It has been shown that IL-8 efficiently triggers all aspects of neutrophil activation including shape change, chemotaxis, granule release and respiratory burst, i.e. generation of reactive oxygen species [4]. GRO-family chemokines, however, are significantly weaker activators of neutrophils in terms of both efficiency and efficacy when compared to IL-8 $[17,26]$. It is possible that IL-17A regulates neutrophil recruitment and subsequent activation by orchestrating a local chemokine environment, the composition of which differs depending on the nature of the tissue and/or organ affected. Thus, appropriate attraction and activation of neutrophils in the lungs, by virtue of the respiratory microvascular endothelium, may require a distinct chemokine profile different from that of the dermal microvascular endothelium reflecting dissimilarities between the two tissues in terms of architecture, cellular environment and external exposure. The differences in neutrophil-activating properties between IL- 8 and GROfamily chemokines could be of central importance in this context and would provide an adequate explanation as to why IL-17A seems to mediate cytokine expression profiles that differ between cell types. In support of this notion, we observed that IL-17A had no effect on the expression of nonneutrophil-specific chemokines such as CXCL10, CXCL11 and MCP-1 in HDMEC, although IL-17A has been reported to modulate both basal and TNF $\alpha$-induced expression of these chemokines in other cell types [27, 34].

Neutrophil adhesion

Selectins (P-selectin and E-selectin) are the first adhesion molecules to interact with circulating leukocytes and allow leukocyte chemokine receptors to engage their ligands presented on the endothelium surface. This, in turn, triggers a more firm adhesion facilitated by ICAM- 1 and VCAM-1. Eselectin is a "promiscuous" molecule in the sense that it can interact with all major types of leukocytes $[6,18,28]$. Which of these are then allowed to adhere firmly and subsequently extravasate is determined by the specific nature of the chemokines presented (neutrophil recruiting, e.g. GRO $\alpha$, or non-neutrophil recruiting, e.g. CXCL10). VCAM-1, however, can only interact with non-neutrophil leukocytes as its counter receptor VLA- $4 \alpha$ is not expressed on human neutrophils but is expressed on human eosinophils and basophils [6]. We found that in HDMEC, IL-17A only affects the expression of cytokines specifically involved in controlling neutrophil recruitment. Furthermore, an investigation of HDMEC adhesion molecule expression revealed that IL-17A does not augment TNF $\alpha$-induced VCAM-1 (Fig. 3b). These data are consistent with IL-17A being neutrophil specific since these cells cannot engage VCAM-1. In fact, our data show that on both the mRNA and protein levels, VCAM-1 is slightly downregulated after $24 \mathrm{~h}$ of stimulation (Table 2). In contrast, we here show that IL-17A significantly potentiates TNF $\alpha$ stimulated E-selectin expression, whereas levels of ICAM-1 are only slightly augmented in comparison. Taken together, our results are in agreement with the notion that in HDMEC, IL-17A only regulates factors controlling neutrophil biology.

It has previously been shown that E-selectin levels in HDMEC directly correlate with the number of adhering neutrophilic cells [43]. Moreover, both E-selectin and ICAM-1 are necessary for cytokine-stimulated transmigration of neutrophils to occur, as shown by studies using blocking antibodies directed against these adhesion molecules $[31,52]$. We here show that the IL-17A-mediated potentiation of TNF $\alpha$ induced E-selectin expression correlates with an equally increased ability of human neutrophils to adhere to an HDMEC monolayer (Fig. 4a, b). Furthermore, our data revealed a significant increase in neutrophil passage albeit not to an extent which matched its effect on neutrophil adhesion. It was recently shown in a mouse endothelial cell model that IL-17A and TNF $\alpha$ act in a synergistic manner to induce an endothelial cell activation and that neutrophil migration is mediated by its CXCR2 expression [19]. We found that a Pselectin-specific antibody did not affect the adherence of neutrophils to endothelial cell monolayer after 24-h stimulation with TNF $\alpha+$ IL-17A contrary to the effect of an antibody against E-selectin (Fig. 4d). We interpret this finding as being due to the high E-selectin expression on the endothelial cell surface compared to P-selectin. Cells had not been exposed to agonists such as thrombin or histamine that promotes transfer of P-selectin to the plasma membrane.

We have used a static system (no simulation of blood flow) to assay the transmigration potential of neutrophils resting on a confluent monolayer of HDMEC. Therefore, initial establishment of contact between neutrophils and endothelial cells did not, to the same extent, depend on E-selectin-mediated "stickiness" as it does in vivo. Given that neutrophil transmigration downstream of E-selectin depends on ICAM-1 and given that IL-17A only had a modest effect on the expression of this protein as compared to E-selectin, our system could not be expected to reveal the true potential of IL-17A in the recruitment of neutrophils as could be expected under in vivo conditions.

We found that IL-17A alone had no effect on neutrophil activation as measured by their ability to adhere to a 
fibrinogen substratum and their generation of superoxide radicals. These data are in agreement with the finding that only IL-17RA is present on neutrophils. We could not detect expression of IL-17RC transcripts using reverse-transcribed neutrophil total RNA, despite the fact that the IL-17RCspecific primers used were designed to allow amplification of all known splice variants. An IL-17RA transcript was, however, readily detectable.

The cooperative and synergistic actions on TNF $\alpha$-induced secretion of neutrophil-specific cytokines, together with the ability to prolong TNF $\alpha$-induced E-selectin expression as shown here, are likely to be mechanisms by which IL-17A causes an enhanced recruitment of neutrophils to sites of inflammation. Thus, we have shown that IL-17A controls mediators of leukocyte trafficking in a highly specific and selective manner via the microvascular endothelium in interaction with TNF $\alpha$. The importance of IL-17A is thus seen when cellular effects are studied in cooperation with other proinflammatory cytokines.

Acknowledgments We are grateful to Wid Talal and Charlotte Therland for the expert technical assistance. This work was supported by Nordea Fonden, NOVO Nordisk Fonden and Center for Healthy Aging (Nordea Fonden).

Open Access This article is distributed under the terms of the Creative Commons Attribution License which permits any use, distribution, and reproduction in any medium, provided the original author(s) and the source are credited.

\section{References}

1. Ahuja SK, Murphy PM (1996) The CXC chemokines growthregulated oncogene (GRO) alpha, GRObeta, GROgamma, neutrophil-activating peptide-2, and epithelial cell-derived neutrophil-activating peptide-78 are potent agonists for the type B, but not the type A, human interleukin-8 receptor. J Biol Chem 271: 20545-20550

2. Andoh A, Takaya H, Makino J, Sato H, Bamba S, Araki Y, Hata K, Shimada M, Okuno T, Fujiyama Y, Bamba T (2001) Cooperation of interleukin-17 and interferon-gamma on chemokine secretion in human fetal intestinal epithelial cells. Clin Exp Immunol 125:56-63

3. Awane M, Andres PG, Li DJ, Reinecker HC (1999) NF-kappa Binducing kinase is a common mediator of IL-17-, TNF-alpha-, and IL-1 beta-induced chemokine promoter activation in intestinal epithelial cells. J Immunol 162:5337-5344

4. Baggiolini M, Clark-Lewis I (1992) Interleukin-8, a chemotactic and inflammatory cytokine. FEBS Lett 307:97-101

5. Benjamin C, Dougas I, Chi-Rosso G, Luhowskyj S, Rosa M, Newman B, Osborn L, Vassallo C, Hession C, Goelz S (1990) A blocking monoclonal antibody to endothelial-leukocyte adhesion molecule-1 (ELAM1). Biochem Biophys Res Commun 171:348-353

6. Bochner BS, Luscinskas FW, Gimbrone MA Jr, Newman W, Sterbinsky SA, Derse-Anthony CP, Klunk D, Schleimer RP (1991) Adhesion of human basophils, eosinophils, and neutrophils to interleukin 1-activated human vascular endothelial cells: contributions of endothelial cell adhesion molecules. J Exp Med 173:1553-1557
7. Cannistra SA, Griffin JD (1988) Regulation of the production and function of granulocytes and monocytes. Semin Hematol 25:173188

8. Chabaud M, Fossiez F, Taupin JL, Miossec P (1998) Enhancing effect of IL-17 on IL-1-induced IL-6 and leukemia inhibitory factor production by rheumatoid arthritis synoviocytes and its regulation by Th2 cytokines. J Immunol 161:409-414

9. Chabaud M, Page G, Miossec P (2001) Enhancing effect of IL-1, IL17 , and TNF-alpha on macrophage inflammatory protein-3alpha production in rheumatoid arthritis: regulation by soluble receptors and Th2 cytokines. J Immunol 167:6015-6020

10. Dudas PL, Sague SL, Elloso MM, Farrell FX (2011) Proinflammatory/ profibrotic effects of interleukin-17A on human proximal tubule epithelium. Nephron Exp Nephrol 117:e114-e123

11. Elbim C, Guichard C, Dang PM, Fay M, Pedruzzi E, Demur H, Pouzet C, El BJ, Gougerot-Pocidalo MA (2005) Interleukin-18 primes the oxidative burst of neutrophils in response to formylpeptides: role of cytochrome b558 translocation and $N$-formyl peptide receptor endocytosis. Clin Diagn Lab Immunol 12:436-446

12. Eriksson A, Cao R, Roy J, Tritsaris K, Wahlestedt C, Dissing S, Thyberg J, Cao Y (2003) Small GTP-binding protein Rac is an essential mediator of vascular endothelial growth factor-induced endothelial fenestrations and vascular permeability. Circulation 107: $1532-1538$

13. Fossiez F, Djossou O, Chomarat P, Flores-Romo L, Ait-Yahia S, Maat C, Pin JJ, Garrone P, Garcia E, Saeland S, Blanchard D, Gaillard C, Das MB, Rouvier E, Golstein P, Banchereau J, Lebecque $\mathrm{S}$ (1996) T cell interleukin-17 induces stromal cells to produce proinflammatory and hematopoietic cytokines. J Exp Med 183: 2593-2603

14. Fox SE, Lu W, Maheshwari A, Christensen RD, Calhoun DA (2005) The effects and comparative differences of neutrophil specific chemokines on neutrophil chemotaxis of the neonate. Cytokine 29: $135-140$

15. Fujino S, Andoh A, Bamba S, Ogawa A, Hata K, Araki Y, Bamba T, Fujiyama Y (2003) Increased expression of interleukin 17 in inflammatory bowel disease. Gut 52:65-70

16. Gaffen SL (2008) An overview of IL-17 function and signaling. Cytokine 43:402-407

17. Geiser T, Dewald B, Ehrengruber MU, Clark-Lewis I, Baggiolini M (1993) The interleukin-8-related chemotactic cytokines GRO alpha, GRO beta, and GRO gamma activate human neutrophil and basophil leukocytes. J Biol Chem 268:15419-15424

18. Graber N, Gopal TV, Wilson D, Beall LD, Polte T, Newman W (1990) T cells bind to cytokine-activated endothelial cells via a novel, inducible sialoglycoprotein and endothelial leukocyte adhesion molecule-1. J Immunol 145:819-830

19. Griffin GK, Newton G, Tarrio ML, Bu DX, Maganto-Garcia E, Azcutia V, Alcaide P, Grabie N, Luscinskas FW, Croce KJ, Lichtman AH (2012) IL-17 and TNF-alpha sustain neutrophil recruitment during inflammation through synergistic effects on endothelial activation. J Immunol 188:6287-6299

20. Guichard C, Pedruzzi E, Dewas C, Fay M, Pouzet C, Bens M, Vandewalle A, Ogier-Denis E, Gougerot-Pocidalo MA, Elbim C (2005) Interleukin-8-induced priming of neutrophil oxidative burst requires sequential recruitment of NADPH oxidase components into lipid rafts. J Biol Chem 280:37021-37032

21. Hammer T, Tritsaris K, Hubschmann MV, Gibson J, Nisato RE, Pepper MS, Dissing S (2009) IL-20 activates human lymphatic endothelial cells causing cell signalling and tube formation. Microvasc Res 78:25-32

22. Hirata T, Osuga Y, Takamura M, Kodama A, Hirota Y, Koga K, Yoshino O, Harada M, Takemura Y, Yano T, Taketani Y (2010) Recruitment of CCR6-expressing Th17 cells by CCL 20 secreted from IL-1 beta-, TNF-alpha-, and IL-17A-stimulated endometriotic stromal cells. Endocrinology 151:5468-5476 
23. Iwakura Y, Nakae S, Saijo S, Ishigame H (2008) The roles of IL-17A in inflammatory immune responses and host defense against pathogens. Immunol Rev 226:57-79

24. Kagami S (2011) IL-23 and Th17 cells in infections and psoriasis. Nihon Rinsho Meneki Gakkai Kaishi 34:13-19

25. Kolls JK, Linden A (2004) Interleukin-17 family members and inflammation. Immunity 21:467-476

26. L'Heureux GP, Bourgoin S, Jean N, McColl SR, Naccache PH (1995) Diverging signal transduction pathways activated by interleukin- 8 and related chemokines in human neutrophils: interleukin- 8 , but not NAP-2 or GRO alpha, stimulates phospholipase D activity. Blood 85: $522-531$

27. Lee JW, Wang P, Kattah MG, Youssef S, Steinman L, DeFea K, Straus DS (2008) Differential regulation of chemokines by IL-17 in colonic epithelial cells. J Immunol 181:6536-6545

28. Leeuwenberg JF, Jeunhomme TM, Buurman WA (1992) Role of ELAM-1 in adhesion of monocytes to activated human endothelial cells. Scand J Immunol 35:335-341

29. Liu Z, Miner JJ, Yago T, Yao L, Lupu F, Xia L, McEver RP (2010) Differential regulation of human and murine P-selectin expression and function in vivo. J Exp Med 207:2975-2987

30. Luscinskas FW, Brock AF, Arnaout MA, Gimbrone MA Jr (1989) Endothelial-leukocyte adhesion molecule-1-dependent and leukocyte (CD11/CD18)-dependent mechanisms contribute to polymorphonuclear leukocyte adhesion to cytokine-activated human vascular endothelium. J Immunol 142:2257-2263

31. Luscinskas FW, Cybulsky MI, Kiely JM, Peckins CS, Davis VM, Gimbrone MA Jr (1991) Cytokine-activated human endothelial monolayers support enhanced neutrophil transmigration via a mechanism involving both endothelial-leukocyte adhesion molecule-1 and intercellular adhesion molecule-1. J Immunol 146:1617-1625

32. Moniaga CS, Egawa G, Doi H, Miyachi Y, Kabashima K (2011) Histamine modulates the responsiveness of keratinocytes to IL-17 and TNF-alpha through the H1-receptor. J Dermatol Sci 61:79-81

33. Moseley TA, Haudenschild DR, Rose L, Reddi AH (2003) Interleukin-17 family and IL-17 receptors. Cytokine Growth Factor Rev 14:155-174

34. Numasaki M, Lotze MT, Sasaki H (2004) Interleukin-17 augments tumor necrosis factor-alpha-induced elaboration of proangiogenic factors from fibroblasts. Immunol Lett 93:39-43

35. Onishi RM, Gaffen SL (2010) Interleukin-17 and its target genes: mechanisms of interleukin-17 function in disease. Immunology 129: 311-321

36. Ouyang X, Yang Z, Zhang R, Arnaboldi P, Lu G, Li Q, Wang W, Zhang B, Cui M, Zhang H, Liang-Chen J, Qin L, Zheng F, Huang B, Xiong H (2011) Potentiation of Th17 cytokines in aging process contributes to the development of colitis. Cell Immunol 266:208-217

37. Pietrowski E, Bender B, Huppert J, White R, Luhmann HJ, Kuhlmann CR (2011) Pro-inflammatory effects of interleukin-17A on vascular smooth muscle cells involve NAD(P)H-oxidase derived reactive oxygen species. J Vasc Res 48:52-58

38. Rahman MS, Yamasaki A, Yang J, Shan L, Halayko AJ, Gounni AS (2006) IL-17A induces eotaxin-1/CC chemokine ligand 11 expression in human airway smooth muscle cells: role of MAPK (Erk1/2, JNK, and p38) pathways. J Immunol 177:4064-4071

39. Roussel L, Houle F, Chan C, Yao Y, Berube J, Olivenstein R, Martin JG, Huot J, Hamid Q, Ferri L, Rousseau S (2010) IL-17 promotes p38 MAPK-dependent endothelial activation enhancing neutrophil recruitment to sites of inflammation. J Immunol 184:4531-4537

40. Ruddy MJ, Wong GC, Liu XK, Yamamoto H, Kasayama S, Kirkwood KL, Gaffen SL (2004) Functional cooperation between interleukin-17 and tumor necrosis factor-alpha is mediated by
CCAAT/enhancer-binding protein family members. J Biol Chem 279:2559-2567

41. Schindler U, Baichwal VR (1994) Three NF-kappa B binding sites in the human E-selectin gene required for maximal tumor necrosis factor alpha-induced expression. Mol Cell Biol 14:5820-5831

42. Schwarzenberger P, La RV, Miller A, Ye P, Huang W, Zieske A, Nelson S, Bagby GJ, Stoltz D, Mynatt RL, Spriggs M, Kolls JK (1998) IL-17 stimulates granulopoiesis in mice: use of an alternate, novel gene therapy-derived method for in vivo evaluation of cytokines. J Immunol 161:6383-6389

43. Sepp NT, Gille J, Li LJ, Caughman SW, Lawley TJ, Swerlick RA (1994) A factor in human plasma permits persistent expression of Eselectin by human endothelial cells. J Invest Dermatol 102:445-450

44. Shalom-Barak T, Quach J, Lotz M (1998) Interleukin-17-induced gene expression in articular chondrocytes is associated with activation of mitogen-activated protein kinases and NF-kappaB. J Biol Chem 273:27467-27473

45. Speyer CL, Ward PA (2011) Role of endothelial chemokines and their receptors during inflammation. J Invest Surg 24:18-27

46. Takahashi $\mathrm{H}$, Tsuji $\mathrm{H}$, Hashimoto $\mathrm{Y}$, Ishida-Yamamoto A, Iizuka $\mathrm{H}$ (2010) Serum cytokines and growth factor levels in Japanese patients with psoriasis. Clin Exp Dermatol 35:645-649

47. Walter UM, Ayer LM, Manning AM, Frenette PS, Wagner DD, Hynes RO, Wolitzky BA, Issekutz AC (1997) Generation and characterization of a novel adhesion function blocking monoclonal antibody recognizing both rat and mouse E-selectin. Hybridoma 16:355361

48. Wengner AM, Pitchford SC, Furze RC, Rankin SM (2008) The coordinated action of G-CSF and ELR + CXC chemokines in neutrophil mobilization during acute inflammation. Blood 111:42-49

49. Williams MR, Azcutia V, Newton G, Alcaide P and Luscinskas FW (2011) Emerging mechanisms of neutrophil recruitment across endothelium. Trends Immunol

50. Witowski J, Ksiazek K, Warnecke C, Kuzlan M, Korybalska K, Tayama H, Wisniewska-Elnur J, Pawlaczyk K, Trominska J, Breborowicz A, Jorres A (2007) Role of mesothelial cell-derived granulocyte colony-stimulating factor in interleukin-17-induced neutrophil accumulation in the peritoneum. Kidney Int 71:514-525

51. Witowski J, Pawlaczyk K, Breborowicz A, Scheuren A, Kuzlan-Pawlaczyk M, Wisniewska J, Polubinska A, Friess H, Gahl GM, Frei U, Jorres A (2000) IL-17 stimulates intraperitoneal neutrophil infiltration through the release of GRO alpha chemokine from mesothelial cells. J Immunol 165: 5814-5821

52. Yan HC, DeLisser HM, Pilewski JM, Barone KM, Szklut PJ, Chang XJ, Ahern TJ, Langer-Safer P, Albelda SM (1994) Leukocyte recruitment into human skin transplanted onto severe combined immunodeficient mice induced by TNF-alpha is dependent on E-selectin. J Immunol 152:3053-3063

53. Yan SR, Novak MJ (1999) Diverse effects of neutrophil integrin occupation on respiratory burst activation. Cell Immunol 195:119-126

54. Yao L, Pan J, Setiadi H, Patel KD, McEver RP (1996) Interleukin 4 or oncostatin $\mathrm{M}$ induces a prolonged increase in P-selectin mRNA and protein in human endothelial cells. J Exp Med 184:81-92

55. Ye P, Rodriguez FH, Kanaly S, Stocking KL, Schurr J, Schwarzenberger P, Oliver P, Huang W, Zhang P, Zhang J, Shellito JE, Bagby GJ, Nelson S, Charrier K, Peschon JJ, Kolls JK (2001) Requirement of interleukin 17 receptor signaling for lung $\mathrm{CXC}$ chemokine and granulocyte colonystimulating factor expression, neutrophil recruitment, and host defense. J Exp Med 194:519-527

56. Yu JJ, Gaffen SL (2008) Interleukin-17: a novel inflammatory cytokine that bridges innate and adaptive immunity. Front Biosci 13:170-177 